\section{EPS Invests for Growth}

The meetings of the Executive and $\mathrm{Re}$ view Committees and of the Divisional and Interdivisional Group Chairmen with the EPS President in Geneva on 9 to 11 November 1989 provided an ideal opportunity to review the Society's finances, and to coordinate fundraising activities. Growth is taking place on several fronts and unless measures are taken to provide a sound financial basis it will be difficult to carry out the additional tasks satisfactorily.

Covering the costs of Europhysics News in its new format together with a full-time Editor to handle an enlarged bulletin that contains more new and topical information requires additional income. So too does the Society if it is to remain flexible and efficient enough to respond to the new political and institutional structures that will emerge in Europe in the 1990's.

During his recent visit to Brussels to meet with officials of the CEC, Professor Ricci received a clear indication that the EPS was moving in the correct direction. Participation in the European Community's scientific programmes was discussed in detail with the view to making specific proposals. One immediate outcome is the procedure outlined elsewhere in this issue for seeking support for meetings and conferences.

The EPS cannot meet all the costs of its new activities from its regular income so appeals for help are being made. A vote in Council in March 1990 will be required before the increase in contributions from two of the largest member societies comes into effect in 1991. In the meantime, individual members are being asked to make a voluntary contribution at the same time as they pay their annual membership fees for 1990. Associate members are also being contacted.

It has always been recognised that a vigorous and enterprising Society requires new members. An initiative by the Institute of Physics in Great Britain has so far resulted in over 100 applications from some 300 enquires in 1989. Individual members will also find that a membership application form accompanies their invoices for 1990 in the hope that they will give it to a colleague who is interested in joining the Society and whose name is not in the new address booklet which was mailed to members in October. Finally, membership campaigns within the major research centres and laboratories are being organized, with the aim to convince physicists that joining the EPS is a viable way to participate at the European level.

\section{Deceased}

Readers will be grieved to hear that Professor Edoardo Amaldi and Professor Günter Harbeke died recently. Both will be remembered for their remarkable contributions to European physics. Appreciations will be published in the next issue.

\section{Postdoctoral Position in Experimental Nuclear and Particle Physics}

At the Institute for Intermediate Energy Physics of the Swiss Federal Institute of Technology $(\mathrm{ETH})$ in Zürich, Switzerland, a postdoctoral research position is open.

The current activities include experiments at the $70 \mathrm{MeV}$ cyclotron of the Paul Scherrer Institute in Villigen (formerly Swiss Institute for Nuclear Research, SIN), where the recently developed powerful source of polarized $\beta$-emitters is used to investigate some fundamental symmetries in the weak interaction (righthanded currents, time reversal violation, conserved vector current hypothesis). In addition, experiments at a high energy accelerator are planned.

Candidates should have research experience in particle or nuclear physics (Ph.D.). They are expected to take an active part in the preparation and realization of experiments. The duration of the contract will be initially for one to three years, with the possibility of renewal. The salary will be approx. Sw.Frs. 65000.- to 75000.- per annum, depending on experience and age.

Candidates are invited to send a curriculum vitae and arrange for two letters of reference to

be sent to: Prof. J. Lang, Institut für Mittelenergiephysik, ETH-Zürich, CH-8093 Zürich, Switzerland.

Universität Bern

Physikalisches Institut

\section{ASSISTENT / ASSISTENTIN}

Wir suchen einen Experimentalphysiker mit Doktorat, der die technische Betreuung unserer CAMECA-lonensonde übernehmen und an unseren Forschungsprojekten mitarbeiten soll. Als Assistent wird er auch am Unterricht beteiligt sein.

Die lonensonde ist ein Sekundärionen-Massenspektrometer (SIMS) mit allen nötigen Hilfsinstallationen (u.a. Chemie- und Probenvorbereitungslabor). Sie gehört zur Abteilung für Massenspektrometrie und Raumforschung, die sich mit der Erforschung unseres Planetensystems befasst (Sonnenwind, Magnetosphäre, Kometen, Meteorite, Mondproben). Zur Abteilung gehören eine mechanische und eine Elektronik-Werkstatt.

An der lonensonde arbeiten Doktoranden und Lizentianden aus verschiedenen Gruppen.

Bewerbungen an: Dr. F. Bühler, Physikalisches Institut, Universität Bern, Sidlerstr. 5, CH-3012 Bern Tel. ++41 (31) 654411

\section{Tecbniscbe Hocbscbule Darmstadt}

Im Fachbereich Materialwissenschaft ist eine

\section{Professor (C4)}

für das Fachgebiet Dünne Schichten (Kenn-Nr.: 236) zu besetzen.

Die/der zu Berufende soll auf dem Gebiet der Verfahren zur Herstellung und Charakterisierung dünner Schichten wissenschaftlich ausgewiesen sein.

Der Forschungsschwerpunkt sollte in der Modifikation oder in der Optimierung von Materialeigenschaften in Grenzflächenbereichen für Anwendungen in Natur- und Ingenieurwissenschaften liegen.

Bewerbungen Die Gesellschaft für Schwerionenforschung in Darmstadt ist an sind mit Lebenslauf, wissenschaftlichem Werdegang, Zeugnissen, Literatur- und Patentverzeichnis unter Angabe der Kenn-Nr.: 236 an den Herrn Präsidenten der Technischen Hochschule Darmstadt,

Karolinenplatz 5 6100 Darmstadt, zu senden. einer Zusammenarbeit bei der Modifikation und Charakterisierung von Materialeigenschaften mit Ionenstrahlen interessiert. Bereitschaft zu enger interdisziplinärer Zusammenarbeit innerhalb der Materialwissenschaft sowie mit anderen Fachgebieten wird ebenso erwartet wie die aktive Mitarbeit am Aufbau des Fachbereichs und des Studiengangs Materialwissenschaft. Es gelten die Einstellungsvoraussetzungen des S 39a HUG. Die Technische Hochschule Darmstadt strebt eine Erhöhung des Anteils der Frauen am Personal, insbesondere in den technischen Bereichen an und fordert deshalb qualifizierte Frauen nachdrücklich auf, sich zu bewerben.

Schwerbehinderte werden bei gleicher Eignung bevorzugt.

Bewerbungsschluss: 7. Februar 1990. 